\title{
A Discussion on the Role of Experimental Teaching of Economics and Management in the Cultivation of Outstanding Applied Business Talents
}

\author{
Jun Bu ${ }^{\mathrm{a}}$, Yunfei Huang ${ }^{\mathrm{b}}$, Wen $\mathrm{Xu}^{\mathrm{c}}$, Xianfang Hong ${ }^{\mathrm{d}}$ \\ No. 123, Fengpu Avenue, Fengxian District, Shanghai, China \\ a21090016@sbs.edu.cn, bhuangyf@sbs.edu.cn, \\ csbstracy2009@163.com, d21090104@sbs.edu.cn
}

-National Demonstration Center for Experimental Modern Circulation Education (Shanghai Business School) Exploration and Practice of Business Public Experimental Teaching System

Keywords: Business Public Experiment; Teaching System; Practice

\begin{abstract}
For application-oriented undergraduate universities, experimental teaching has become one of the key links in the process of talent cultivation. National Demonstration Center for Experimental Modern Circulation Education closely sticks to the School's objective of talent cultivation, carries out research on experimental teaching, explores and leads the reform direction of experimental teaching, shares high-quality experimental teaching resources and supports the School's talent cultivation efforts by virtue of high level experimental teaching. With more than 10 years of exploration and practice through three stages, the Center's established business public experimental teaching system plays an active role in cultivating outstanding applied business talents for the School in the aspects of experimental curriculum system construction, teaching and research, and cultivation of innovative and entrepreneurial talents, etc. This paper introduces the construction, achievements and future prospects of business public experimental system.
\end{abstract}

Shanghai Business School sticks to its school-running philosophy of "basing school on business and centering on application", and adheres to the school motto of "striving for virtue and knowledge and governing and benefiting the people". The School bases itself on the industry and emphasizes on application, serves Shanghai with the perspective of facing the entire China. It keeps a close eye on national strategy and Shanghai's development planning, closely follows the comprehensive education reform, adjustment of economic and industrial structural adjustments and industry development trends, and keeps abreast of the demand for the development of Shanghai as international trade center and the perfection of urban functions. According to the talent cultivation thought of centering on educating people, giving priority to moral education, focusing on ability, addressing on all-round development and respecting for individuality, Shanghai Business School strives to cultivate outstanding business talents with social responsibility, practical ability, innovation and entrepreneurship spirit and international vision, to provide talents and intellectual support for serving and leading the development as well as raising the energy level of commercial circulation industry.

Approved as a national experimental teaching demonstration center by the Ministry of Education in July 2013, National Demonstration Center for Experimental Modern Circulation Education (hereinafter referred to as The Demonstration Center, or The Center) is an independently set teaching unit, serving as a teaching base for the School to organize high level experimental teaching and cultivate the practical ability and innovation spirit of students. The primary mission of the Demonstration Center is to insist on strengthening moral education and cultivating people, and focus on the talent strategies and social development needs of Shanghai and China. It closely follows the School's objective of talent cultivation, carries out research on experimental teaching, explores and leads the reform direction of experimental teaching, and shares high-quality experimental teaching resources and supports the School's work of cultivating applied business talents by virtue of high level experimental teaching. 


\section{Meaning and purpose of constructing business public experimental teaching system}

For application-oriented undergraduate universities of finance and economics, experimental teaching has become a key step of talent cultivation. As mainly relying on commerce and trade service industry, Shanghai Business School has set up its majors and talent cultivation scheme highlighting more on the characteristics of commerce and trade service industry, in order to cultivate applied professionals suitable for the related positions of commerce and trade service industry.

According to the definition of United Nations Educational, Scientific and Cultural Organization (UNESCO), applied talents refer to a special type of talents who can apply professional knowledge and skills to the industry's social practice they are engaged in, and technical or professional talents who skillfully grasp the basic knowledge and skills of front-line social production or activities and are mainly engaged in front-line production. The specific connotation of applied talents keeps developing with the development of the history of higher education. Therefore, students have to possess certain level of operational skills as well as general knowledge in commerce and trade enterprise management, as the focus for colleges of finance and economics intend to cultivate applied talents. In other words, students have to develop the basic knowledge of modern management and, to certain extent, understand and master the management mode and method of modern enterprises. This basic school-running philosophy needs to be reflected in the talent cultivation scheme, which means to reflect these most basic management thoughts and methods of business enterprise management as a content of business public experimental teaching of colleges of finance and economics, and the most basic step of talent cultivation. The cultivation of applied talents in commerce and trade needs to strengthen theoretical teaching on the one hand, and to attach more importance to constructing practical teaching on the other hand. The specific practical teaching steps should contain: (1) Business public experimental teaching system; (2) Curriculum experimental teaching system; (3) Professional practice; (4) Graduation practice; (5) Student extracurricular activities, with the construction of business public experimental teaching system as the foundation. Based on business public experimental teaching, the complete practical teaching system of talent cultivation is formed through integrating curriculum practice teaching, professional practice, and extracurricular activities, etc., and combining campus experiments with off-campus practice. As a result, business public experiment is an integrated practice platform which fully reflects the school-running characteristics for commerce and trade service industry of Shanghai Business School and the orientation of cultivating applied talents in commerce and trade.

\section{Construction of business public experimental teaching system}

The Demonstration Center actively participates in the design of the School's cultivation scheme of outstanding applied business talents, and closely sticks to the School's objective of talent cultivation. It focuses on providing independently set business public experimental courses (40 experimental courses are developed in total) with 2 credits each (64 class hours) for all undergraduate students, and completes the experimental teaching work of 4,000 students every year. The business public experimental system of the Center was constructed through three stages:

The First Stage: From 2005 to 2008, the Center broke the School's original single experimental model of dividing subjects by major of each college. Aiming to improve the comprehensive ability and employment ability of students, the Center carried out a comprehensive ability training according to the common demand of modern circulation enterprises for occupational ability. Modern circulation enterprises set up positions separately according to managed objects (information, operation, capital and human resources). Firstly, the Center conducted analysis on the requirements of single ability for modern circulation enterprises and established several experimental projects based on these requirements. Then, it merged these experimental projects to form synthetic courses. Finally, it integrated the courses to form a general education experimental teaching module, namely integrated experimental module of modern circulation enterprise operation. All courses in the module and all experimental projects in courses were not isolated; 
instead, they had coupling correlation in business and data. This correlation highlighted the highsimulation characteristic of connotation. The Center had won many outstanding achievements based on the construction of experimental teaching system of general education and professional practice, and was successfully approved as an experimental teaching demonstration center of Shanghai City—Circulation Modernization Experimental Teaching Demonstration Center. (Figure 1)

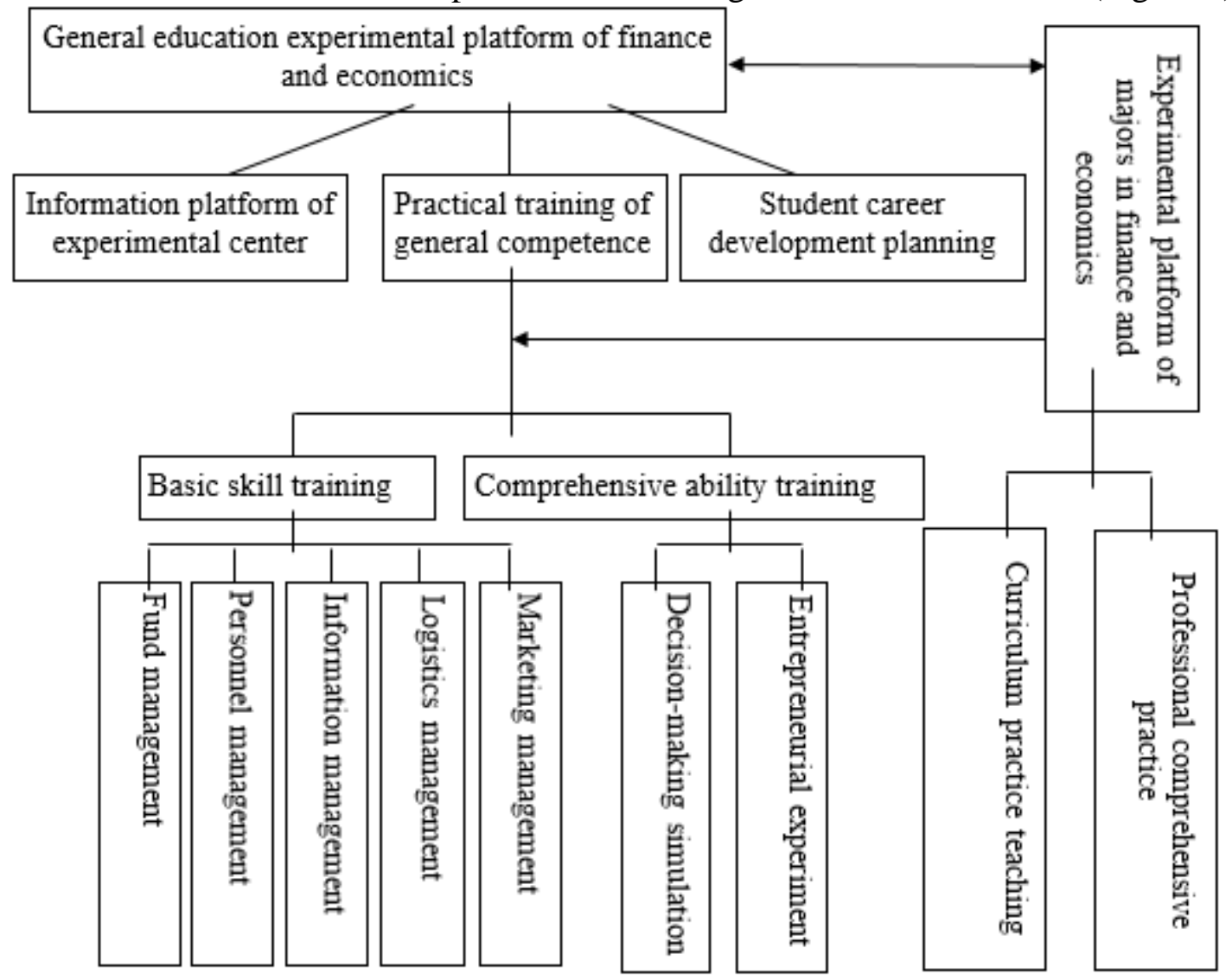

Fig. 1 Teaching system of general education and professional practice

The Second Stage: From 2008 to 2013, the Center had paid high attention to the need from circulation industry on the total number, specialty, capability and other aspects of talents. It comprehensively analyzed relevant data from more than 100 domestic and foreign enterprises in the circulation industry, fully communicated with experts from government human resources departments, social research institutions, etc. Therefore by preliminarily setting up the objective of business and management capabilities required by enterprise positions of the circulation industry, the tenet of cultivating the innovation spirit and entrepreneurship awareness of students, and the foundation of modern circulation experimental service platforms, the Center made progressive experimental contents run through the whole process of cultivating business talents by means of operational, process-based, decision-making and research-based business public experiments and professional experiments. Table 1 shows the analytical table for the capabilities of modern circulation talents. Based on the above constructive contents and significant achievements, the Center was successfully approved as a national experimental teaching demonstration centerNational Demonstration Center for Experimental Modern Circulation Education in 2013. 
Table 1 Parsing table for capabilities of modern circulation talents

(The table of capability cultivation demand developed according to enterprise requirements)

\begin{tabular}{|c|c|c|c|}
\hline Item & Detail & Definition or explanation & $\begin{array}{l}\text { Level of } \\
\text { experimental } \\
\text { practice }\end{array}$ \\
\hline \multirow{5}{*}{ Basic literacy } & Basic knowledge & \multirow{5}{*}{$\begin{array}{l}\text { Possess cultural knowledge and professional } \\
\text { basic knowledge required by engaging in } \\
\text { economic management activities, } \\
\text { Skills in reading, writing and speaking, and } \\
\text { application skills of modern technical means, } \\
\text { Comprehensive quality such as professional } \\
\text { consciousness, loyalty, ethics and behavior } \\
\text { showed in professional process, } \\
\text { Know, understand and properly manage emotion, } \\
\text { Understand others from their standpoints to } \\
\text { achieve the harmony of interpersonal } \\
\text { relationships, and } \\
\text { Have the ability of bearing pressure and setbacks, } \\
\text { etc. }\end{array}$} & \multirow{5}{*}{$\begin{array}{l}\text { Focus on general } \\
\text { applicable } \\
\text { experiments across } \\
\text { all levels }\end{array}$} \\
\hline & Basic skill & & \\
\hline & Professionalism & & \\
\hline & $\begin{array}{l}\text { Emotional Quotient } \\
\text { (EQ) }\end{array}$ & & \\
\hline & $\begin{array}{l}\text { Adversity Quotient } \\
\text { (AQ) }\end{array}$ & & \\
\hline \multirow{6}{*}{$\begin{array}{l}\text { Management } \\
\text { capabilities }\end{array}$} & $\begin{array}{l}\text { Comprehension and } \\
\text { expression capability }\end{array}$ & \multirow{6}{*}{$\begin{array}{l}\text { Possess the capabilities of understanding } \\
\text { management standards, identifying and } \\
\text { correcting execution deviations, namely } \\
\text { improving management capabilities through } \\
\text { process-based and decision-making experiments. } \\
\text { From the perspective of actual operation of } \\
\text { modern circulation, management capabilities } \\
\text { mainly refer to the ability of managing people, } \\
\text { finance, things, information, knowledge, } \\
\text { techniques and performance, and controlling the } \\
\text { processes of business activities. }\end{array}$} & \multirow{6}{*}{$\begin{array}{l}\text { Decision-making } \\
\text { experiments }\end{array}$} \\
\hline & $\begin{array}{l}\text { Continuous } \\
\text { improvement } \\
\text { capability }\end{array}$ & & \\
\hline & $\begin{array}{l}\text { Data analysis } \\
\text { capability }\end{array}$ & & \\
\hline & $\begin{array}{l}\text { Management and } \\
\text { decision-making } \\
\text { capability }\end{array}$ & & \\
\hline & $\begin{array}{c}\text { Process control } \\
\text { capability }\end{array}$ & & \\
\hline & $\begin{array}{l}\text { Personnel } \\
\text { organization } \\
\text { capability }\end{array}$ & & \\
\hline \multirow{5}{*}{ Business capabilities } & $\begin{array}{c}\text { Circulation cognitive } \\
\text { capability }\end{array}$ & \multirow{5}{*}{$\begin{array}{l}\text { Possess the technical and practical operation } \\
\text { capabilities obtained by long-term training in } \\
\text { certain business activity. } \\
\text { From the perspective of actual operation of } \\
\text { modern circulation, business capabilities mainly } \\
\text { refer to the ability of applying modern } \\
\text { technology and engaging in all kinds of business } \\
\text { activities based on supply chain cooperative } \\
\text { relationship. }\end{array}$} & \multirow{5}{*}{$\begin{array}{l}\text { Operational and } \\
\text { process-based } \\
\text { experiments }\end{array}$} \\
\hline & $\begin{array}{c}\text { Operational activity } \\
\text { capability }\end{array}$ & & \\
\hline & Marketing capability & & \\
\hline & $\begin{array}{l}\text { Technical } \\
\text { application } \\
\text { capability }\end{array}$ & & \\
\hline & $\begin{array}{l}\text { Industrial core } \\
\text { capability }\end{array}$ & & \\
\hline
\end{tabular}




\begin{tabular}{|c|c|c|c|}
\hline $\begin{array}{c}\text { Innovation and } \\
\text { entrepreneurship } \\
\text { capabilities }\end{array}$ & $\begin{array}{c}\text { Creative thinking } \\
\text { capability }\end{array}$ & $\begin{array}{l}\text { Possess the ability of coming up with unique and } \\
\text { innovative ideas based on business and } \\
\text { management capabilities to solve problems under } \\
\text { certain situations, } \\
\text { Have entrepreneurship awareness and be able to } \\
\text { select entrepreneurship projects according to } \\
\text { market environment, develop and implement } \\
\text { entrepreneurial plans, integrate social resources, } \\
\text { implement effective management and realize } \\
\text { successful entrepreneurship. }\end{array}$ & $\begin{array}{c}\text { Comprehensive } \\
\text { experiments on } \\
\text { innovation and } \\
\text { entrepreneurship } \\
\text { based on the above } \\
\text { three types of } \\
\text { experiments }\end{array}$ \\
\hline
\end{tabular}

The Third Stage: Since 2013 up to now, the Center has adapted to the development trend of modern commercial circulation industry, further integrated experimental teaching resources, strengthened the development of experimental teaching team, improved informatization level and gradually perfected the experimental teaching system of "Three Levels, Four Modules and Four Modes" (see Fig. 2), as according to the requirements of talent cultivation objectives. These actions closely follow the deepening of the School's comprehensive reform and the advance of constructing applied undergraduate pilot majors in Shanghai City (8 majors including Business Administration have been approved as applied undergraduate pilot majors of Shanghai City).

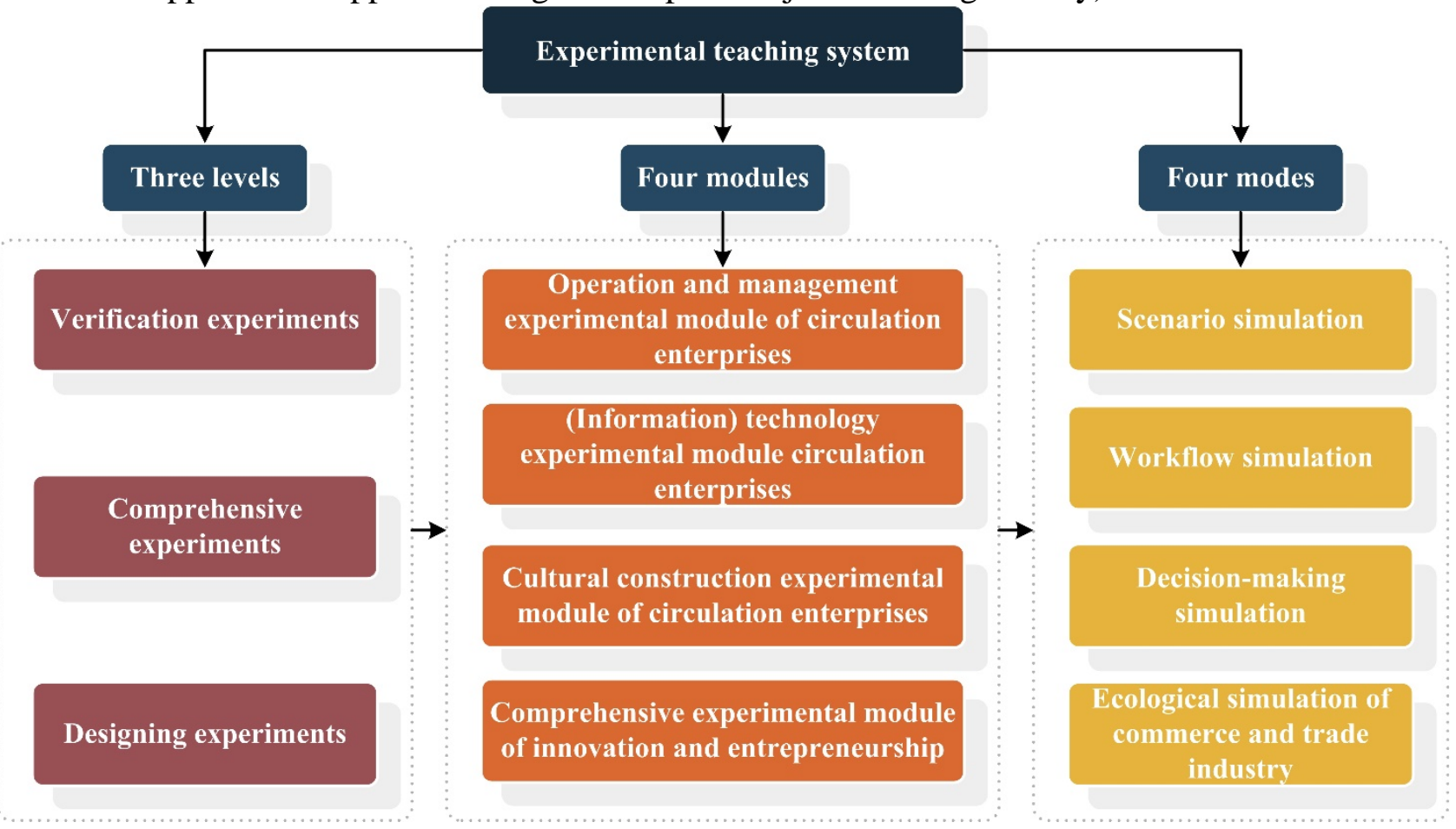

Fig. 2 Experimental teaching system of “Three Levels, Four Modules and Four Modes”

\section{Practice and preliminary achievements of business public experimental teaching system}

1) Take a variety of measures to implement the talent cultivation scheme. The Demonstration Center closely sticks to the school's objective of talent cultivation and focuses on providing a total of 40 independently set business public experimental courses with 2 credits each (64 class hours) to all undergraduate students, with 4,000 students attending these courses in each academic year. In addition, The Demonstration Center has set up "Teaching Quality Monitoring Leadership Team” and "Teaching Supervision Group of Teaching and Research Department", regularly carries out collective teaching and research activities, implements class auditing system and gives timely feedbacks so as to support and boost teachers of business public experimental courses to improve and elevate their teaching continuously, raise the management level of teaching, promote the construction of teaching quality assurance resource system of business public experiments and 
ensure the quality and efficiency of specialty development. The average score of student's evaluation on the teaching quality of teachers of business public experimental courses is over 92 .

2) Actively carry out studies, reform and scientific research on teaching. In recent 5 years, The Demonstration Center has set up 11 school-enterprise horizontal research topics to support its courses, 8 School-level teaching and research reform projects, 7 School-level key course development projects, as well as 2 School-level new courses, 1 municipal-level high-quality online course and 8 virtual simulation experimental teaching projects. The Demonstration Center has cooperated with Tsinghua University Press to publish 7 textbooks for experimental teaching, won the First Prize of municipal-level Teaching Achievement Award once, the Third Prize of municipallevel Education and Teaching Research Award once, Teaching Achievement Award of the School 4 times, and 53 software copyrights.

3) Carry out various kinds of academic competitions. In recent three years, The Demonstration Center has hosted, held, or organized students to participate in 15 academic competitions at all levels, by itself or cooperating with related secondary colleges. More than 11,000 person-time of students participated in these academic competitions. 49 person-time of students have won municipal-level awards, and 29 person-time of students have won national awards.

4) Support the innovation and entrepreneurship education of the School. In recent three years, The Demonstration Center has guided 33 student entrepreneurship projects (6 municipal projects and 6 national projects) and won one first prize and one second prize in the Shanghai area finals of the China National College Students “Innovation, Originality and Entrepreneurship” Challenge.

5) Deepen school-enterprise cooperation and extend high-quality teaching resources. The Demonstration Center explores the construction of innovation and entrepreneurship education system taking school-enterprise and industry-university-research cooperation as the bond. The Center makes the most of various resources to provide strong support of the innovation and entrepreneurship education to students. In the teaching of courses like Virtual Entrepreneurship Practice, enterprise executives and entrepreneurial alumni are invited to give lectures, provide employment guidance and guide the career planning for students.

6) Share resources and receive high recognition by virtue of its experimental system. Initiated by The Demonstration Center in 2012, five universities (Shanghai Business School, Shanghai University of Finance and Economics, University of Shanghai for Science and Technology, Chongqing University and Zhejiang University of Finance \& Economics) have reached to the agreement of sharing teaching resources, including mutual recognition of credits, sharing of syllabus and teaching plans, and unification of experimental teaching textbooks and handbooks. This "Five College Alliance" has carried out teaching activities and academic competitions based on a virtual simulation experimental teaching platform, and offered one experimental course called Practical Training of Innovation and Entrepreneurship. In 2017, the number of participating universities reached up to 66 .

7) Informatization construction, open operation and demonstration exposure. Regarding experimental contents which are hard to be carried out in real experimental platforms during the process of actual classroom teaching and experiments, with high complexity and cost, long cycle and wide range, The Demonstration Center takes advantage of professional simulation software and self-developed virtual simulation experimental system, to construct a three-dimensional and multilayered virtual simulation experimental teaching platform with a high sense of reality and accuracy. In 2017, The Demonstration Center received 14 visits from sister colleges and institutions across the country.

\section{Future prospect for the construction of business public experimental teaching system}

The business public experimental teaching system of The Demonstration Center has been run for more than 10 years with outstanding achievements. However, we still need to continually improve in the following aspects:

1) Develop Preliminary Planning for the Construction of Virtual Simulation Experimental Teaching Projects and promote the development of virtual simulation projects. To implement the 
spirit of Notice of the General Office of Ministry of Education on Carrying out the Construction of Demonstration Virtual Simulation Experimental Teaching Projects from 2017 to 2020 (the Ministry of Education [2017] No. 4), the Center conducted a comparative analysis on the setup situation of existing subjects and majors of the School with the planning catalogue of the Ministry of Education, developed a preliminary planning for the construction of virtual simulation experimental teaching projects of the School. In 2017, 8 projects were initiated within the School, and the Center has been actively promoting these projects.

2) Declare the school-enterprise collaborative education project of the Ministry of Education and improve the innovation and entrepreneurship education system. Apart from integrating the existing course system of innovation and entrepreneurship education, The Demonstration Center should make full use of off-campus resources, explore new mechanism of cultivating talents through cooperation between universities and industry enterprises, follow the talent cultivation mode of "diverse cooperation and collaborative education", and cooperate with related companies to actively declare the collaborative education project of the Ministry of Education. The School and enterprises should play their respective advantages to improve the cultivation quality and level of innovative and entrepreneurial talents. In addition, The Demonstration Center should strengthen its innovation and entrepreneurship education, and improve the comprehensive practical capabilities of students through the launch of collaborative education project and with the help of software platforms of the enterprises.

3) Perfect the informatization construction of business public experimental teaching platforms. The Center shall further improve and perfect its experimental teaching network platforms and experimental teaching management information system, relying on the foundation of the School as a demonstration of national smart campus, to effectively integrate existing platforms through the construction of intelligent experimental management system, and realize intelligent management and provide inter-university and trans-regional high-speed network access capability.

4) Perfect the management system and mechanism of business public experimental teaching. The Center shall further perfect the existing management system and operating mechanism, to fully display the role of functional departments, secondary colleges and The Demonstration Center of the School, and ensure the stability and promotion of business public experimental teaching faculties. The Center must guarantee to provide sufficient and high-quality resources for business public experimental teaching and improve the incentive policy of faculties of experimental teaching.

With a clear idea of development and reform, the business public experimental teaching of The Demonstration Center actively connects with the construction of applied pilot majors of the School, achieves obvious effects in promoting the coordinated development of entrepreneurial knowledge, capabilities and quality of students, constantly strengthens school-enterprise cooperation and produces significant demonstration exposure effects. In the future, the Center will make all efforts to play a greater role in cultivating outstanding applied business talents.

\section{References}

[1] Xiong Sidong. General Education and Universities: China’s Exploration. Science Press. 2010

[2] Gao Haiqing. Introduction to the General Education Courses of Independent Colleges. National Defense Industry Press. 2014

[3] Yu Shuxiu, Sun Qi, Jiang Linlin. Research on University General Education. Jiuzhou Press. 2014

[4] General Education in a Free Society Report of the Harvard Committee. Peking University Press. 2010

[5] I. Westbury, N.J. Wilkof. Science, Curriculum and General Education. China Light Industry Press. 2008

[6] General Education under the Mode of Flipped Classroom. Huang Guanqun. 
http://www.xchen.com.cn/dyjy/tongshijiaoyulunwen/676519.html .2018

[8] Improvement of Educational Competitiveness by General Education. Xiang Zheng. http://www.xchen.com.cn/dyjy/tongshijiaoyulunwen/676183.html.2018

[9] Development Path of General Education in Modern Universities. Jiang Xia. http://www.xchen.com.cn/dyjy/tongshijiaoyulunwen/676181.html.2018

[10] Innovative General Education. http://www.xchen.com.cn/dyjy/tongshijiaoyulunwen/666033.html.2018

[11] General versus vocational education: Lessons from a quasi-experiment in Croatia, Ivan Zilic, Economics of Education Review, 2018.1-11

[12] HEAD teachers managing entrepreneurship education e Empirical evidence from general education, Elena Ruskovaaraa, *, Minna $\mathrm{H} €$ €m $€$ al $€$ ainena, Timo Pihkala, Teaching and Teacher Education, 2016. 155-164

[13] Integrating creative photography pedagogy in general education, Li-Hsun PENG a, Sieng-Hou CHEN, Procedia - Social and Behavioral Sciences 217, (2016) 183 - 191

[14] Short- and long-term effects of assessment-based differentiated reading instruction in general education on reading fluency and reading, Natalie Förster*, Elisabeth Kawohl, Elmar Souvignier, Learning and Instruction,2018.98-109, comprehension

[15] Teaching systems thinking to general education 1 students, George E. Mobus, Ecological Modelling, 2018.12-21 